\title{
LIETUVOS IRKLUOTOJŲ RENGIMOSI ATĖNŲ OLIMPINĖMS ŽAIDYNĖMS OLIMPINIO KETURMEČIO CIKLO ANALIŻ்
}

\author{
Einius Petkus ${ }^{1}$, Algirdas Raslanas ${ }^{1}$, Sigita Kibildiené ${ }^{2}$, Linas Tubelis ${ }^{1}$ \\ Vilniaus pedagoginis universitetas ${ }^{1}$, Vilnius, Klaipedos apskrities Sporto medicinos centras ${ }^{2}$, Klaipèda, \\ Lietuva
}

Einius Petkus. Sporto magistras, Vilniaus pedagoginio universiteto doktorantas. Lietuvos irklavimo federacijos vyriausiasis treneris. Moksliniu tyrimų kryptis — sportininkų rengimas, didelio meistriškumo irkluotojų rengimas ir adaptacija prie fizinių krūvių.

\begin{abstract}
SANTRAUKA
Irklavimas yra viena iš 28 olimpiniu sporto šaku, kuriu dalyviu skaičius yra labai didelis, laimima 14 komplektu medaliu. Irklavima kultivuoja 119 pasaulio šaliu. Lietuvoje irklavimo populiaruma riboja daugelis veiksniu. Lietuvos irkluotojai yra pasiekę dideliu laimèjimu, tačiau Atènu olimpinèms žaidynèms gerai pasirengti nepavyko.

Tyrimo tikslas — išanalizuoti Lietuvos olimpinès rinktinès rengima olimpiniu ciklu ir irkluotoju fiziniu galiu kaita. Tyrimo objektas — Lietuvos olimpinès rinktinès rengimas keturmečiu ciklu, funkcinio irkluotoju pajégumo ir fiziniu galiu kaita.

Tyrème septynis irkluotojus (W2x, M2x, M2-, M1x igulas), kurie rengési Atėnu olimpinèms žaidynėms.

Buvo nagrinèti varžybu protokolai, treneriu apskaitos dokumentai, sportininku dienoraščiai. Tyrimai atlikti pagal „Atėnai 2004“ programa. Tiriamuju metiniu rengimosi ciklu varžybu tvarkaraštis per olimpini keturmeti cikla skyrèsi nedaug. Metinio ciklo apimtis ir intensyvumas per keturmeti cikla kito. Bendrasis krūvis atskirais metais svyravo nuo 700 iki 1350 valand $u$. Per metus buvo nuirkluojama 2500-3500 km, 70—75\% dirbta aerobinio ugdymo zonoje, 25-30\% skirta darbui virš anaerobinio slenksčio ribos ir iš ju 5\% - ties kritinio intensyvumo ir maksimaliu pastangu ribomis. Sportininkai dalyvaudavo 8-11 varžybu, startavo 20-30 kartu per metus.

Tiriamuju fizinis išsivystymas kito nedaug. Fiziniu galiu ir funkcinio pajégumo rodikliai kito nevienodai, o irkluotoju specialusis darbingumas atliekant 10 ir 30 s irklavimo ergometru darba per keturmeti cikla padidejo. Aerobiniu galiu bei kraujotakos ir kvépavimo sistemos pajégumas kito banguotai $\left(\mathrm{VO}_{2}\right.$ max $\left.50-80 \mathrm{ml} / \mathrm{min} / \mathrm{kg}\right)$, bet dažniausiai buvo vidutinis ar nepakankamas pagrindiniu varžybu metu. Galima manyti, kad per pagrindines keturmečio ciklo varžybas anaerobiniu alaktatiniu, glikolitiniu ir aerobiniu energijos gamybos būdu išugdymo santykis nebuvo optimalus. Rengiantis Pekino olimpinėms žaidynèms, reikètu ypač stiprinti irkluotoju aerobines galias bei didinti ju kraujotakos ir kvépavimo sistemos funkcini pajéguma.
\end{abstract}

Raktažodžiai: irkluotoju rengimas, fizinès galios, funkcinis pajėgumas, treniruočiu programa, irkluotoju rengimo kontrole ir valdymas.

\section{IVADAS}

$\mathrm{D}$ idelio meistriškumo irkluotojų rengimas olimpinėms žaidynėms yra kompleksiškas procesas, sudètingas ilgametis vyksmas. Keturmetis olimpinis ciklas susideda iš metinių rengimo ciklų, kurių struktūrą ir turini lemia atskirų treniruotès etapų uždaviniai, sportininkų fizinių ir funkcinių galių kaita, igulų komplektavimo strategija, ekonominiu, socialinių bei gamtiniu sąlygų ypatumai. Rengimą olimpinèms žaidynèms lemia kokybiška ir laiku atlikta kandidatų atran$\mathrm{ka}$, treniruotès individualizavimas atsižvelgiant $\mathfrak{i}$ sportininko genotipą ir asmenines savybes, taip pat finansinès, materialinės galimybės, metodiniai, moksliniai ir medicininiai resursai. Olimpinio ciklo rengimo sistemos kaita leidžia lanksčiau planuoti ir operatyviai keisti treniruočių programa, atsižvelgiant i sporto šakos plètros tendencijas, pokyčius varžybu kalendoriuje, rengimo priemonių ir inventoriaus tobulèjimą (Дрюков, 2003). Metinis treniruotės ciklas apima visas sportinio rengimo sudedamąsias dalis. Jị apibūdina sudètinga kreivè, kuri priklauso nuo sportininko organizmo būklès, varžybų kalendoriaus (jų dažnumo, pertraukų, svarbiausių sezono varžybų) ir išorinių sąlygų. 
Sportininkus rengiantys treneriai, remdamiesi išsamia praėjusio sezono analize, savo darbo patirtimi ir moksliniais tyrimais, teorinėmis žiniomis ir loginiu mąstymu, sudaro metinius treniruotés planus (Матвеев, 1999; Драгунов, 2003).

Literatūroje yra duomenų apie geriausių pasaulio irkluotojų makrociklu, mikrociklu ir pratybu struktūrą, sportininkų fiziologinius, techninius ir taktinius rengimo aspektus (Hagerman et al., 1978, 1995; Hagerman, 1984; Secher, 1993; Steinacker, 1993; Kleshnev, 2001; Nilsen, 2001 ir kiti), tačiau dažnai informacija būna per daug reliatyvi, kad būtų galima ją taikyti rengiant Lietuvos irkluotojus. Lietuvos sportininkų rengimą analizavo A. Raslanas (1998), E. Kemerytè-Riaubienė (2000), J. Skernevičius ir kt. (1997, 2004), V. Štaras ir kt. (2001), tačiau rengimas per keturmeti olimpini ciklą mažai nagrinètas, o nauji tyrimų duomenys yra svarbūs sporto mokslo plètotei, didelio meistriškumo irkluotojų rengimo tobulinimui.

Atsižvelgiant ị ne visada irklavimui palankias Lietuvos klimato, ekonomines bei socialines sąlygas, svarbu ištirti Lietuvos irkluotojų keturmečio ciklo rengimo specifinius ypatumus. Būtina išsiaiškinti, kaip geriau rengti Lietuvos irkluotojus varžyboms, kokybiškai taikant šiuolaikinę sportininkų rengimo vadybą.

Hipotezè: tikimasi, kad išanalizavus Lietuvos olimpinės rinktinės irkluotojų rengimą per keturmeti ciklą, bus galima nustatyti šio rengimo ypatumus, ir tai padès sėkmingiau rengtis pasaulio čempionatams ir olimpinėms žaidynėms, geriau realizuoti irkluotoju potencines galias.

Tikslas - išanalizuoti Lietuvos olimpinès rinktinès rengimą ir jo trūkumus per olimpini ciklą, nustatyti irkluotojų fizinių galių kaitą.

Tyrimo objektas - Lietuvos irkluotojų rengimas olimpiniu keturmečiu ciklu.

Uždaviniai:

1. Ištirti bendrus metinio treniruočių krūvio parametrus, jų kaitą per ketverius metus.

2. Nustatyti irkluotojų specialiojo parengtumo, aerobinio pajėgumo ties anaerobinio slenksčio ir kritinio intensyvumo ribomis dydžius kiekvienais keturmečio ciklo metais.

3. Ivertinti irkluotojų rengimo kontrolès efektyvumą.

\section{TYRIMO METODAI}

Tyrème septynis irkluotojus (W2x, M2x, M2, M1x igulas), kurie rengèsi Atėnų olimpinėms žaidynėms. Irkluotojų išplėstiniai tyrimai buvo atliekami kiekvienais olimpinio ciklo metais VPU Sporto mokslo institute ir Vilniaus sporto medicinos centre. Tyrimus atlikome pagal programoje „Atėnai 2004“ (2001) numatytą irkluotojų medicininių ir biologinių tyrimų programą bei metodus (Skernevičius ir kt., 2004). Buvo analizuojami varžybų rezultatu protokolai, nagrinejjami ir vertinami metiniai treniruočiu planai. Tirti fizinio išsivystymo rodikliai: ūgis, kūno masè, raumenų ir riebalų masè, jų santykis, plaštakų jèga, gyvybinè plaučių talpa (GPT). Buvo nustatyta: psichomotorinès reakcijos greitis (PRG); judesių dažnis per $10 \mathrm{~s}$; vienkartinis raumenu susitraukimo galingumas (VRSG); anaerobinis alaktatinis raumenu galingumas (AARG). Nustatytas specialusis anaerobinis alaktatinis galingumas atliekant $10 \mathrm{~s}$ maksimaluji darbą, fiksuojant vidutinę ir didžiausią momentinę galią, mišrus anaerobinis alaktatinis glikolitinis dirbant $30 \mathrm{~s}$, glikolitinis — irklavimo ergometru Concept 2 iveikiant $500 \mathrm{~m}$, pulso dažnis (PD) ties anaerobinio slenksčio riba ir raumenų galingumas (W). Kraujotakos ir kvėpavimo sistemų funkcini pajejgumą vertinome pagal Rufjè indeksą (RI), taip pat nustateme reakciją $\mathfrak{i}$ ortostatini mėgini ir standartinị fizini krūvị (30 pritūpimų per 45 s), atsigavimo eigą. Ištyrème hemoglobino $(\mathrm{Hb})$ koncentraciją kraujyje ir hematokritą (Ht), laktato kieki (La) kraujyje po maksimaliojo krūvio. Aerobines galias tyrème dujų analizatoriumi Ergooxyscreen, raumenų galingumą didindami irklavimo ergometru Concept 2, taip pat nustatėme deguonies $\left(\mathrm{O}_{2}\right)$ suvartojima, plaučiu ventiliaciją (PV), deguonies pulsą (DP), pulso dažni (PD), raumenų galingumą (W), darbo ekonomiškumą ties kritinio intensyvumo (KIR) ir anaerobinio slenksčio (AS) ribomis.

\section{REZULTATAI}

Vertinant 2001-2002 m. tarptautinèse regatose ir pasaulio čempionatuose Lietuvos irkluotojų pasiektus rezultatus, buvo planuota, kad penkios igulos iškovos kelialapius į olimpines žaidynes. Deja, irkluotojams neatlikus reikiamo aerobinio fizinio krūvio ir nepasiekus pakankamo aerobinio pajègumo rodiklių (Hagerman et al., 1978, 1995; Nilsen, 1993), planas nebuvo įvykdytas.

Visas keturias igulas treniravo skirtingi treneriai. Dèl ịvairių valčių klasių specifikos ir treniruočių individualizavimo rengimosi programos skyrėsi, tačiau tiriamujų varžybų tvarkaraštis bei jų atlikto fizinio krūvio kiekybiniai rodikliai atskirais 
1 lentelè. Fizinio krūvio 2001-2004 m. kiekybiniai rodikliai

\begin{tabular}{|c|c|c|c|c|c|}
\hline \multirow{2}{*}{ Krūvio pobūdis } & \multirow{2}{*}{ Valčiu klasė } & \multicolumn{4}{|c|}{ Metai } \\
\hline & & 2001 & 2002 & 2003 & 2004 \\
\hline \multirow{4}{*}{$\begin{array}{l}\text { Pratybu dienų } \\
\text { skaičius }\end{array}$} & M2x & 153 & 221 & 234 & 231 \\
\hline & W2x & 148 & 221 & 194 & 188 \\
\hline & M2- & 310 & 298 & 290 & 250 \\
\hline & M1x & 280 & 306 & 312 & 270 \\
\hline \multirow{4}{*}{ Pratybų skaičius } & M2x & 239 & 332 & 334 & 339 \\
\hline & W2x & 216 & 316 & 268 & 261 \\
\hline & M2- & 600 & 430 & 490 & 450 \\
\hline & M1x & 500 & 510 & 570 & 490 \\
\hline \multirow{4}{*}{$\begin{array}{l}\text { Pratybų valandu } \\
\text { skaičius }\end{array}$} & M2x & 460 & 653 & 702 & 682 \\
\hline & W2x & 298 & 412 & 332 & 298 \\
\hline & M2- & 1355 & 1203 & 1150 & 1100 \\
\hline & M1x & 920 & 1150 & 1200 & 1000 \\
\hline \multirow{4}{*}{$\begin{array}{l}\text { Nuirkluotu } \\
\text { kilometrų } \\
\text { skaičius }\end{array}$} & M2x & 2100 & 3250 & 3500 & 3300 \\
\hline & W2x & 2180 & 2505 & 1830 & 1300 \\
\hline & M2- & 3500 & 2920 & 2950 & 2700 \\
\hline & M1x & 2000 & 2400 & 3000 & 2400 \\
\hline \multirow{4}{*}{ Varžybų skaičius } & M2x & 9 & 9 & 11 & 10 \\
\hline & W2x & 8 & 8 & 7 & 8 \\
\hline & M2- & 11 & 9 & 9 & 8 \\
\hline & M1x & 10 & 10 & 11 & 9 \\
\hline
\end{tabular}

metinių ciklų rengimosi laikotarpiais skyrèsi nedaug. Tik moterų porinė dvivietė turejjo mažesnius krūvius (per metus krūvio apimtis tesudarydavo $\sim 50 \%$ ir mažiau kitų igulų atlikto krūvio), sportininkes dažniau kamavo traumos. Bendras krūvis atskirais metais svyravo nuo 700 iki 1350 valandų. Per metus buvo nuirkluojama 2500-3500 km (1 lent.), $70-75 \%$ dirbta aerobinio ugdymo zonoje, 25-30\% skirta darbui virš anaerobinio slenksčio ribos, 5\% iš jų - ties kritinio intensyvumo ir maksimaliu pastangų ribomis. Sportininkai dalyvavo 8-11 varžybų, startavo $20-30$ kartu per metus. Visų tirtų irkluotojų pereinamasis laikotarpis tęsdavosi aštuonias savaites ir daugiau.

Lyginant keturmečio ciklo atskirus metinius krūvius matyti, kad tirtų Lietuvos irkluotojų igulų atlikto darbo valandu skaičius, ypač olimpiniais metais, mažèjo. Tai lėmè varžybų kalendorius ir moteru porinès dvivietès (W2x), vyrų bevairès dvivietės (M2-), vyrų vienvietės (M1x) atrankos i olimpines žaidynes neįveikimas. Visgi vyrų porinès dvivietès (M2x-), M2- ir M1x igulų irkluotojams pavykdavo nuirkluoti panašų kilometrų skaičiu per visą olimpini ciklą. W2x olimpinio ciklo fiziniu krūvių kaitą daugiau lėmè sportininkių traumos, bet ne nuoseklus planavimas. 2002, 2003-iaisiais ir olimpiniais metais tirti irkluotojai kovo, balandžio mèn. rengèsi Ispanijoje ir Šveicarijoje, ir tai leido parengiamuoju laikotarpiu padidinti ant vandens nuirkluotų kilometrų skaičių.

Visais olimpinio ciklo metais irkluotojai dalyvavo pagrindinèse FISA varžybose, išskyrus olimpines žaidynes, i kurias pateko tik M2x. $2001 \mathrm{~m}$. Liucernos pasaulio čempionate W2x iškovojo penktą vieta, M2x ir M2- - aštuntas vietas. $2002 \mathrm{~m}$. Sevilijos pasaulio čempionate W2x iškovojo septintą, M2- - aštuntą, M2x — dešimtą vieta. M1x Genujos pasaulio jaunimo čempionate užèmé ketvirtą vietą. $2003 \mathrm{~m}$. Milano pasaulio čempionate vyko atrankos i olimpines žaidynes pirmas etapas ir tik vyru porinè dviviete, iškovojusi 11 vieta, pateko i olimpines žaidynes. M2užèmè 13 , W1x -15 vietą. S. K., irkluodamas vienvietę valti, Belgrado pasaulio jaunimo čempionate iškovojo sidabro medali, tačiau dèl ligos negalėjo dalyvauti pasaulio čempionate Milane. 2004 m. Liucernoje, finalinejje atrankos į olimpines žaidynes regatoje, nė viena Lietuvos igula neįvykdè kvalifikacinių normatyvų. 2003 ir 2004 m. W2x igulos nariai nuolat keitèsi. Nors bazinio rengimo ir parengiamuju varžybų etapai vykdavo sklandžiai, pagrindinėse varžybose igula dèl įvairiu priežasčiu iširdavo ir $2003 \mathrm{~m}$. pasaulio čempionate užèmè 15 vieta, o $2004 \mathrm{~m}$. atrankos regatoje Liucernoje 
2 lentelè. Aerobinio pajègumo 2001-2004 m. tyrimų duomenys

\begin{tabular}{|c|c|c|c|c|c|c|c|c|c|c|c|c|c|c|c|c|c|c|c|c|}
\hline \multirow{3}{*}{ Tiriamieji } & \multicolumn{20}{|c|}{ Data } \\
\hline & $\begin{array}{l}\overrightarrow{0} \\
\overrightarrow{8} \\
\stackrel{\circ}{v}\end{array}$ & $\begin{array}{l}\text { 노 } \\
\stackrel{\circ}{\circ} \\
\stackrel{\circ}{ }\end{array}$ & 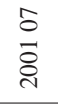 & $\begin{array}{l}\text { ㄱ. } \\
\text { 공 } \\
\text { ㅇ }\end{array}$ & $\begin{array}{l}\text { ปิ } \\
\text { ปิ } \\
\text { ఠิ }\end{array}$ & 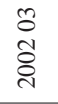 & 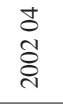 & 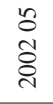 & $\begin{array}{l}\text { ડ } \\
\text { ปิ } \\
\text { ઠे }\end{array}$ & $\begin{array}{l}\text { I } \\
\text { ปิ } \\
\text { ઠे }\end{array}$ & $\begin{array}{l}m \\
\text { o } \\
\stackrel{2}{0} \\
\stackrel{\nu}{0}\end{array}$ & $\begin{array}{l}\varnothing \\
\text { ஜి } \\
\stackrel{\nu}{~}\end{array}$ & 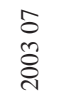 & 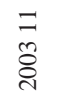 & 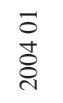 & 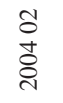 & $\begin{array}{l}\text { ஜ } \\
\text { Iे } \\
\text { ¿े }\end{array}$ & 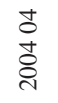 & 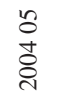 & 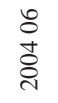 \\
\hline & \multicolumn{20}{|c|}{ Kritinio intensyvumo riba, $\mathrm{VO}_{2} \mathrm{ml} / \mathrm{min} / \mathrm{kg}$} \\
\hline E. $\check{S}$ & 63,6 & 63,4 & 63,0 & & & 61,2 & 58,7 & 53,6 & 66,4 & 71,2 & 61,2 & 66,2 & 66,7 & 65,5 & & & & 58,5 & & 60,1 \\
\hline K. K. & 63,1 & 66,2 & & & & 65,3 & 70,6 & 68,2 & 81,2 & 72,2 & 65,7 & 62,0 & 65,3 & 65,8 & & 70,5 & & & & 73,5 \\
\hline K. P. & 51,9 & 56,1 & & 50,7 & & & 53,0 & 44,6 & 67,1 & & & 55,3 & & & & & 62,1 & 67,5 & & \\
\hline B. Š. & 44,7 & & 41,2 & 47,0 & & 53,7 & & 44,3 & 57,2 & 55,1 & 46,2 & 45,7 & & 46,1 & & & 52,8 & 53,6 & 61,5 & \\
\hline E. P. & 57,4 & 60,6 & 74,1 & 57,9 & 56,5 & & 69,2 & & 65,0 & & 53,6 & & & & 63,2 & & & 65,3 & & \\
\hline G. Ž. & 50,5 & 69,7 & 69,4 & 57,2 & 61,3 & & 83,2 & & 71,9 & & 64,0 & & & 68,1 & 66,9 & & & 68,2 & & \\
\hline \multirow[t]{2}{*}{ S. K. } & & & & & & & & 76,0 & & 72,4 & 63,2 & 64,0 & & & & 74,3 & & & & \\
\hline & \multicolumn{20}{|c|}{ Anaerobinio slenksčio riba, $\mathrm{VO}_{2} \mathrm{ml} / \mathrm{min} / \mathrm{kg}$} \\
\hline E. Š & 44,9 & 44,0 & 47,8 & & & 46,7 & 40,4 & 40,5 & 44,1 & 51,6 & 47,5 & 48,8 & & 45,3 & & & & 49,2 & & 53,9 \\
\hline K. K. & 38,5 & 43,0 & & & & 59,4 & 49,3 & 45,3 & 69,5 & 56,1 & 44,8 & 46,4 & 46,0 & 58,7 & & 40,0 & & & & 59,6 \\
\hline K. P. & 38,4 & 35,0 & & 41,0 & & & 46,7 & 37,4 & 57,4 & & & 49,6 & & & & & 40,9 & 48,8 & & \\
\hline B. Š. & 29,1 & & 30,0 & 31,8 & & 44,1 & & 39,6 & 50,9 & 45,7 & 40,4 & 37,7 & & 35,5 & & & 44,8 & 49,6 & 54,5 & \\
\hline E. P. & 49,7 & 40,0 & 48,2 & 39,0 & 38,6 & & 35,7 & & 40,2 & & 41,2 & & & & 47,3 & & & 55,2 & & \\
\hline G. Ž. & 39,6 & 44,0 & 35,2 & 43,2 & 42,7 & & 50,1 & & 50,8 & & 45,6 & & & 46,1 & 53,6 & & & 60,0 & & \\
\hline S. K. & & & & & & & & 56,4 & & 51,0 & 46,7 & 46,1 & & & & 30,9 & & & & \\
\hline
\end{tabular}

3 lentelè. Anaerobinio alaktatinio ir mišraus anaerobinio alaktatinio galingumo 2001-2004 me. tyrimų duomenys

\begin{tabular}{|c|c|c|c|c|c|c|c|c|c|c|c|c|c|c|c|c|c|c|c|c|c|c|}
\hline \multirow{3}{*}{ Tiriamieji } & \multicolumn{22}{|c|}{ Data } \\
\hline & $\begin{array}{l}\vec{\sigma} \\
\overrightarrow{0} \\
\overrightarrow{0}\end{array}$ & $\begin{array}{l}\text { n̊ } \\
\vec{\circ} \\
\stackrel{0}{\circ}\end{array}$ & $\begin{array}{l}\hat{o} \\
\vec{\circ} \\
\text { ¿े }\end{array}$ & $\begin{array}{l}\vec{\exists} \\
\overrightarrow{8} \\
\overrightarrow{0}\end{array}$ & 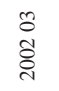 & 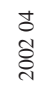 & 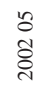 & $\begin{array}{l}\hat{\text { o }} \\
\text { ठे } \\
\text { ठे }\end{array}$ & $\begin{array}{l}\infty \\
\stackrel{\text { o }}{\text { Oे }}\end{array}$ & 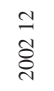 & 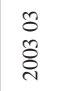 & 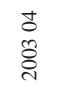 & $\begin{array}{l}\stackrel{0}{ } \\
\text { ڤิ } \\
\stackrel{N}{ }\end{array}$ & $\begin{array}{l}\text { oे } \\
\text { ڤે } \\
\text { ¿े }\end{array}$ & 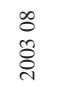 & 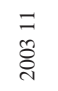 & 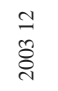 & \begin{tabular}{l} 
ô \\
+े \\
\multirow{N}{N}{}
\end{tabular} & $\begin{array}{l}\text { r } \\
\text { +े } \\
\stackrel{\text { dे }}{ }\end{array}$ & 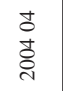 & 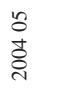 & $\begin{array}{l}\text { oे } \\
\text { +े } \\
\text { ¿्रे }\end{array}$ \\
\hline & \multicolumn{22}{|c|}{$10 \mathrm{~s}$ max momentinė reikšmé, $\mathrm{W}$} \\
\hline E. Š & 910 & 862 & 999 & 909 & 928 & 962 & 1038 & 1046 & 1050 & 921 & 1007 & & 1042 & 1034 & 1097 & 1046 & 1010 & 1031 & 1150 & 1096 & 1101 & 1146 \\
\hline K. K. & 993 & 981 & 1029 & 970 & 941 & 1007 & 1003 & 988 & 1027 & 1013 & & & 1058 & 1104 & 1134 & 1015 & 1029 & 1104 & 1149 & 1153 & 1165 & 1143 \\
\hline K. P. & 729 & 727 & & 705 & & 728 & 719 & 717 & & & & & & & & & & 693 & 727 & 726 & 723 & \\
\hline B. S̆. & 701 & & 723 & 688 & 722 & & 711 & 722 & & 720 & 716 & & & 701 & & 707 & & 712 & 728 & 719 & 719 & \\
\hline E. P. & 1040 & 1024 & 1007 & 1028 & 1030 & 1061 & & 1028 & & 1075 & 1047 & 1070 & 1085 & 1050 & & & & & 1068 & 1083 & & \\
\hline G. Ž. & 1074 & 1000 & 1032 & & 1022 & 1069 & & 1065 & & 1133 & 1166 & 1074 & 1047 & 1070 & & 1080 & 1063 & & 1117 & 1097 & & \\
\hline \multirow[t]{2}{*}{ S. K. } & & & 779 & 832 & 910 & 967 & 911 & 941 & & 951 & 941 & & 909 & 933 & & 999 & 993 & 1005 & & & 1018 & \\
\hline & \multicolumn{22}{|c|}{30 s max vidutinè reikšmé, $\mathrm{W}$} \\
\hline E. Š & 651 & 674 & 712 & 637 & 737 & 761 & 787 & 770 & 774 & 760 & 704 & 784 & 735 & 797 & 864 & 765 & & 770 & 872 & 810 & 820 & 880 \\
\hline K. K. & 786 & 779 & 806 & 771 & 789 & 789 & 797 & 805 & 849 & 833 & & 857 & 781 & 911 & 939 & 841 & 874 & 913 & 955 & 955 & 938 & 935 \\
\hline K. P. & 605 & 598 & & 531 & & 614 & 586 & 605 & & & & 561 & & & & & & 599 & 611 & 591 & 588 & \\
\hline B. Š. & 568 & & 574 & 558 & 589 & & 577 & 586 & & 583 & 571 & 571 & & 567 & & 575 & 548 & 582 & 592 & 591 & 587 & \\
\hline E.P. & 835 & 787 & 830 & 793 & 798 & 876 & & 850 & & 865 & 869 & & & & & & & & 850 & & & \\
\hline G. Ž. & 839 & 763 & 819 & & 791 & 856 & & 902 & & 939 & 950 & & & & & 883 & 841 & & 905 & & & \\
\hline S. K. & & & 665 & 708 & 732 & 772 & 742 & 760 & & 774 & 806 & 822 & 719 & 776 & & 839 & 814 & 839 & & & & \\
\hline
\end{tabular}

Š. B. startavo vienviete valtimi (W1x). Sportininkẻ turejo per mažai laiko įvaldyti vienvietès irklavimo specifiką ir pasiekti rezultatai neparodė potencinių irkluotojos galimybių. M2x valties igulai nepavyko gerai pasirengti ir $2004 \mathrm{~m}$. Atėnų olimpinėse žaidynèse ji užèmė tik 14 vieta.

Analizuojant irkluotojų fizinio išsivystymo duomenų kaitą per keturmeti ciklą matyti, kad rodikliai kito nedaug ir dèsningai. Pereinamuoju ir parengiamuoju laikotarpiu tiriamujų masė padidėdavo, o parengiamuju ir pagrindinių varžybų metu sumažèjus riebalų masei (didejjant raumenu riebalų masės indeksui) ji vèl optimizuodavosi.
Fizinių galių ir funkcinio pajègumo rodikliai kito netolygiai.

Per keturmeti ciklą sportininkų aerobinis pajegumas ties kritinio intensyvumo ir anaerobinio slenksčio ribomis irkluojant ergometru su dujų analizatoriumi M2x buvo nustatytas 14 kartu (3-4 k. per metini cikla), W2x - 12-13 kartu (3-4 k. per metini ciklą), M2- - 11 kartu ( $2-3 \mathrm{k}$. per metus). Vienvietininko S. K. aerobinės galios dujų analizatoriumi pradètos tirti $2002 \mathrm{~m}$. Buvo atlikti penki tyrimai. Santykinis deguonies suvartojimas ties kritinio intensyvumo riba visų tiriamujų kito banguotai $\left(\mathrm{VO}_{2 \max } 50-80 \mathrm{ml} / \mathrm{min} / \mathrm{kg}\right)$, o pajè- 
gumas ties anaerobinio slenksčio riba pagrindiniu varžybų metu būdavo nepakankamas (2 lent.). M2x ir M1x igulų irkluotoju specialusis darbingumas atliekant 10 ir $30 \mathrm{~s}$ darbą irklavimo ergometru per keturmeti ciklą labai išaugo (3 lent.). E. Š. $10 \mathrm{~s}$ maksimalių pastangų darbo galingumas nuo tyrimo pradžios išaugo nuo 910 iki $1150 \mathrm{~W}$ olimpiniais metais, K. K. — nuo 993 iki 1165 W. Minètu igulu $30 \mathrm{~s}$ (Vingeito testas) darbo galingumas per keturmeti ciklą išaugo vidutiniškai $200 \mathrm{~W}$. M2- igulos nariui E. P. 10 ir $30 \mathrm{~s}$ darbo rodikliai kito nereikšmingai, o G. Ž. anaerobinis pajègumas bangavo per visą olimpini ciklą. W2x šie rezultatai kito nedaug ir buvo optimalūs, $10 \mathrm{~s}$ darbo galingumo didžiausia momentinè reikšmè svyravo nuo 688 iki $729 \mathrm{~W}, 30 \mathrm{~s}$ - vidutinè reikšmė buvo nuo 531 iki 614 W. Tirtu irkluotojų (vyrų) galingumas ties kritinio intensyvumo riba per keturmeti ciklą svyravo nuo 460 irki $550 \mathrm{~W}$. Irklavimo galingumas ties anaerobinio slenksčio riba buvo $250-370 \mathrm{~W}$. Visų tiriamujų kraujotakos ir kvėpavimo sistemos pajėgumas kito banguotai, bet dažnai buvo vidutinis ar nepakankamas, o prieš pagrindines varžybas nepasiekdavo reikiamo lygio.

\section{REZULTATŲ APTARIMAS}

Per pirmus ketverius ciklo metus Lietuvos irkluotojai pasieke geru rezultatu, bet nepatenkinami olimpinio ciklo pabaigos rezultatai rodo, kad nepakankamai buvo i̇vertinti irkluotojų rengimo ypatumai, ne visai tinkamai parinkta treniruočiu metodika.

Lietuvos irkluotojų specialiojo fizinio krūvio apimtis ir intensyvumas ne visada buvo pakankami dèl šiu priežasčių: parengiamaisiais laikotarpiais - dèl netinkamų irklavimui ant vandens oro sąlygų (irklavimo ant vandens didelės apimties pageidaujamus fizinius krūvius irkluotojai keisdavo slidinèjimu, bėgimu, čiuožimu ir irklavimu ergometru Concept 2), varžybiniais - dèl traumu, varžybu tvarkaraščio ir didelių atstumų iki varžybų vietos. Neigiamos įtakos turejo ir per ilgas pereinamasis laikotarpis, kuris kartais tęsdavosi tris mėnesius vietoj rekomenduotino vieno (Платонов, 1997). Pereinamuoju laikotarpiu tirtu irkluotojų fizinès ir funkcinės galios smarkiai sumažèdavo, kai tuo tarpu kitų šaku pajėgių sportininkų pereinamasis laikotarpis trunka tik 2-4 savaites ir jų parengtumas per ši laikotarpi kinta labai mažai (Balčiūnas ir kt., 2005). Lietuvos igulų irklavimo ant vandens trukmé buvo per maža ir tesudare $50 \%$ V. N. Platonovo ir kitų autorių siūlomo nuirkluotų kilometrų skaičiaus (Платонов, 1997).

Sportininkų ir treneriu pateiktuose sporto treniruotės dienoraščiuose bei planavimo ir apskaitos dokumentuose trūksta aiškiai apibrèžtų krūvio apimties ir intensyvumo rodiklių parametrų.

\section{IŠVADOS}

1. Tiriamujų aerobinis pajègumas ties anaerobinio slenksčio ir kritinio intensyvumo ribomis kiekvienais keturmečio ciklo metais buvo per daug banguotas, nebuvo pastovus šio rodiklio didejjimo lygis, o prieš atsakingas varžybas jis nepasiekdavo ir optimalaus. Irklavimo galingumas ties anaerobinio slenksčio riba sudarydavo tik 55-75\% kritinès intensyvumo ribos galingumo, kai gerai treniruotų irkluotojų šis rodiklis turètų būti 80-85\% (Steinacker, 1993). Taigi, sudarant irkluotojų rengimo programas, būtina didinti aerobinio pajègumo ugdymo apimtị iki 70-80\% viso metinio krūvio (Steinacker, 1993; Hagerman, 1995).

2. Išanalizavus tyrimo rezultatus galima teigti, kad per pagrindines keturmečio ciklo varžybas ivveikiant 2000 m nuotoli, anaerobinių alaktatinių, glikolitinių ir aerobinių energijos gamybos būdų santykis nebuvo optimalus. Rengiantis Pekino olimpinėms žaidynėms, reikètu ypač stiprinti irkluotojų aerobines galias bei jų kraujotakos ir kvėpavimo sistemos funkcini pajėgumą.

3. Išsami mokslinių ir medicininių tyrimų programa leido realiai ivvertinti irkluotoju organizmo adaptaciją prie fizinių krūvių, jų parengtumo kaita.

\section{LITERATŪRA}

Balčiūnas, E., Rudzinskas, M., Švedas, E., Skernevičius, J. (2005). Baidarininku rengimo olimpiniu ciklu analizè. Sporto mokslas, 2 (40), 41-45.

Hagerman, F. C. (1984). Applied physiology of rowing. Sports Medicine, 1, 303-326.

Hagerman, F. C., Conors, M. C., Gault, J. A., Hagerman G. R., Polionski W. J. (1978). Energy expenditure during simulated rowing. Journal of Applied Physiology, 45, 87-93.

Hagerman, F. C., Fielding, R. A., Fiatarone, M. A., Gault, J. A., Kirkendall, D. T., Ragg, K. E., Evans, W. J. (1995). A 20-year longitudinal study of Olympic oarsmen (Eine 20jährige Längsschnittuntersuchung von Olympiateilnehmernim Rudern). Medicine and Science 
in Sports and Exercise, (28), 9, 1150-1156.

Kemerytė-Riaubienè, E., Raslanas, A. (2000). Irkluotoju fizinių ir funkcinių galių tyrimai. Sporto mokslas, 1 (19), $35-37$.

Kleshnev, V. (2001). Racing strategy in rowing during Sydney Olympics. Australian Rowing, 24 (1), 20-23.

Nilsen, T. S. (1993). Elite sports and coaching development of the future. FISA-coach, (4), 2, 1-4.

Raslanas, A. (1998). Aerobinių ir anaerobinių rodiklių taikymas irkluotojų rengime. Sporto mokslas, 3 (12), 28-30.

Raslanas, A., Skernevičius, J. (1998). Sportininku testavimas. Vilnius.

Skernevičius, J., Raslanas, A., Dadelienè, R. (2004). Sporto tyrimu metodologija. Vilnius.

Skernevičius, J., Raslanas, A., Petkus, E., Opalnikova, A., Kibildienè, S. (2004). Lietuvos rinktinès irkluotojų fizinio išsivystymo ir parengtumo bei funkcinio pajègumo analizè. Sporto mokslas, 1 (35), 39-43.

Skernevičius, J. (1997). Sporto treniruotès fiziologija. Vilnius.
Secher, N. H. (1993). Physiological and biomechanical aspects of rowing. Implications for training. Sport Medicine, 15, 24-42.

Steinacker, J. M. (1993). Pysiological aspects of rowing. International Sports Medicine, 14, 53-510.

Štaras, V., Arelis, A., Venslovaitè, L. (2001). Lietuvos moterų irkluotojų treniruotes vyksmo ypatumai. Sporto mokslas, 4 (26), 28-31.

Драгунов, Л. (2003). Особливости подугови підготовки спортсменів в олімпійских циклах. Теорія і методика фізичного выхования, 1, 8-10.

Дрюков, В. А. (2003). Система построения четырёхлетних циклов подготовки спортсменов высокого класса к играм олимпиад в современном пятиборье. Наука в олимпийском спорте, 1, 11-22.

Матвеев, Л. П. (1999). Основы общей теории спорта и системы подготовки спортсменов. Киев: Олимпийская литература.

Платонов, В. Н. (1997). Общая теория подготовки спортсменов в олимпйском спорте. Киев.

\title{
ANALYSIS OF ROWERS’ TRAINING FOR THE ATHENS OLYMPIC GAMES OVER THE FOUR-YEAR OLYMPIC CYCLE
}

\author{
Einius Petkus ${ }^{1}$, Algirdas Raslanas ${ }^{1}$, Sigita Kibildiene $\dot{e}^{2}$, Linas Tubelis ${ }^{1}$ \\ Vilnius Pedagogical University ${ }^{1}$, Vilnius, Sports Medicine Centre of Klaipéda’s District ${ }^{2}$, Klaipèda, \\ Lithuania
}

\begin{abstract}
The aim of our work was to analyze the process of training and the dynamics of physical performance of rowers-members of the Lithuanian national Olympic team.

We examined seven rowers (W2x, M2x, M2x, M1x crews) who were training for the Athens Olympic Games.

The investigation followed the "Athens 2004" programme. The regatta schedule of an annual cycle underwent changes over the four-year period. Total annual load in separate years varied from $~ 700$ to 1350 hours. The annual distance of rowing reached $2500-3500 \mathrm{~km} ; 70-75 \%$ of work proceeded in the aerobic development zone, 25-30\% comprised work above the anaerobic threshold, about 5\% of them within critical intensity and maximal strain limits. The physical development of the study subjects changed insignificantly. The physical performance and functional capacity indices showed various dynamics. Special performance of M2x and M1x crew members under the 10-s and 30-s rowing on an ergometer over the four-year cycle increased very significantly. From the beginning of study up to the Olympic year, the 10-s maximum strain power increased in E. Š. from $910 \mathrm{~W}$ to $1150 \mathrm{~W}$ and in K. K. from $993 \mathrm{~W}$ to $1165 \mathrm{~W}$. The 30 s working power increased on average by $200 \mathrm{~W}$. In other rowers this dynamics was less pronounced. The aerobic and circulatory-respiratory performance showed a wavy dynamics $\left(\mathrm{VO}_{2 \max } 50-80 \mathrm{ml} / \mathrm{kg} / \mathrm{min}\right)$, but it was mostly medium or insufficient in the periods of main competitions.

There are reasons to believe that in the key competitions of the four year cycle the ratio of anaerobic alactic, glycolytic and aerobic ways energy production was not optimal. Therefore, while performing for the Peking Olympic Games, particular attention should be given to increasing the functional abilities of the circulatory and respiratory systems.
\end{abstract}

Keywords: preparation of rowers, physical and functional capacity, training program, rower's preparation management.

Gauta 2005 m. spalio 25 d.

Received on October 25, 2005
Einius Petkus

Vilniaus pedagoginis universitetas (Vilnius Pedagogical University) Studentų g. 39, LT-08106 Vilnius Lietuva (Lithuania)

Tel +370 52734858

E-mail lunabase@centras.lt 